\title{
Corrosion Characteristics of Hydrogen Permeation Materials in Molten Salt Flinak
}

\author{
Takuya NAGASAKA, Masatoshi KONDO, Akio SAGARA and Takeo MUROGA \\ National Institute for Fusion Science, Toki, Gifu 509-5292, Japan
}

(Received 2 October 2010 / Accepted 10 August 2011)

\begin{abstract}
Corrosion characteristics of hydrogen-permeation materials (e.g., Pd-Ag, pure V, Nb, and Ta) are examined in molten salt Flinak, in order to develop a hydrogen-recovery section for a Flinak forced convection loop "Operational Recovery of Separated Hydrogen and Heat Inquiry -1 (Orosh $\left.{ }^{2} \mathrm{i}-1\right)$." It is determined that their corrosion rate is not significant at $873 \mathrm{~K}$ under static conditions, compared with that of JLF-1 ferritic steel. However, pure $\mathrm{V}$ indicates a relatively high weight gain, likely due to $\mathrm{O}$ absorption. Dissolution of highly radioactive elements (e.g., $\mathrm{Ag}$ and $\mathrm{Nb}$ ) is also indicated. The corrosion mechanisms and characteristics of the constituent elements are analyzed.
\end{abstract}

(C) 2011 The Japan Society of Plasma Science and Nuclear Fusion Research

Keywords: liquid breeder blanket, Flibe, Flinak, palladium-silver, group 5 elements

DOI: $10.1585 /$ pfr.6.1405146

\section{Introduction}

The liquid breeder blanket is promising for DEMO and commercial fusion reactors. Molten salt Flibe $(\mathrm{LiF}+$ $\left.\mathrm{BeF}_{2}\right)$ is an attractive liquid breeder material because of its non-reactivity with air and water, low vapor pressure leading to low operation pressure, low tritium inventory, and low MHD pressure loss [1]. In the liquid breeder blanket system, the breeder is circulated between the reactor core and the outside as a coolant. The fuel tritium and heat generated in the blanket are transferred by the molten salt, and then they are extracted by a tritium-recovery system and a heat-recovery system located outside the reactor core. In order to maintain high thermal efficiency for the heatrecovery system, the tritium-recovery system should be operated at high temperature (i.e., $823 \mathrm{~K}$ of the blanket outlet temperature). Hydrogen recovery in a liquid breeder blanket system is a challenge characterized by high temperature operation and recovery from the liquid, while the current hydrogen system is operated below $673 \mathrm{~K}$ in a gas atmosphere. A vacuum disengager making Flibe droplets [2] and a Flibe/He counter-current extraction tower [3] have been proposed as tritium-recovery systems for the blanket. The latter system recovers tritium through hydrogenpermeation metal windows between flowing Flibe and He.

Recently, a project entitled "Operational Recovery of Separated Hydrogen and Heat Inquiry -1 (Orosh $\left.{ }^{2} \mathrm{i}-1\right)$ " was initiated at the National Institute for Fusion Science. The Orosh $^{2} \mathrm{i}-1$ is a forced convection loop using molten salt Flinak $(\mathrm{LiF}+\mathrm{NaF}+\mathrm{KF})$ as a simulant for Flibe. It integrates the numerous elemental studies on the molten salt blanket system, and demonstrates the compatibility of hydrogen recovery and heat recovery. One of the first missions

author'se-mail: nagasaka@nifs.ac.jp is an evaluation of the hydrogen recovery performance of hydrogen-permeation window materials.

Generally, the corrosion rate of the materials increases with increasing operation temperature; therefore, the lifetime of hydrogen-permeation materials is potentially determined by corrosion at $873 \mathrm{~K}$, the operation temperature for Orosh ${ }^{2} \mathrm{i}-1$. In the present study, the corrosion characteristics of hydrogen-permeation materials in Flinak were investigated to evaluate their feasibility for the Orosh ${ }^{2} \mathrm{i}$ 1 project and future Flibe blanket systems. Corrosion tests for a relatively short time $(304 \mathrm{hr})$ under static condition were conducted prior to flowing condition tests in the Orosh ${ }^{2}$ i-1 loop, in order to clarify the fundamental compatibility of the candidate hydrogen-permeation materials with Flinak.

\section{Experimental}

The prepared candidate hydrogen-permeation materials were $\mathrm{Pd}-25 \mathrm{wt} \% \mathrm{Ag}$, pure $\mathrm{V}, \mathrm{Nb}$, and Ta with a purity of 99.9 99.99\%. Their $1 \mathrm{~mm}$-thick plates were cut into corrosion specimens that were $15 \times 10 \times 1 \mathrm{~mm}$. These specimens were annealed in a vacuum at $973 \mathrm{~K}$ for $1 \mathrm{hr}$. The corrosion specimens were exposed to Flinak molten salt at $873 \mathrm{~K}$ for $304 \mathrm{hr}$ under static conditions using 316L stainless steel (Fe- $18 \mathrm{Cr}-8 \mathrm{Ni}-2 \mathrm{Mo}-0.5 \mathrm{Mn}-0.5 \mathrm{Si}$ ) crucible. One crucible contained one specimen of the hydrogenpermeation materials. Four grams of Flinak was used for each specimen. Electrochemical corrosion enhances the corrosion rate if dissimilar metals are in contact with each other. In the present study, the corrosion specimens were hung from a $\mathrm{Al}_{2} \mathrm{O}_{3}$ insulator with the same metal wire to avoid contact and electrochemical corrosion. After exposure, weight change was determined by an electrobalance. 
The surface was analyzed using a scanning electron microscope (SEM) and an X-ray photoelectron spectrometer (XPS). The Flinak used was chemically analyzed before and after the corrosion tests by inductively coupled plasma (ICP) - mass spectroscopy (Fe, Cr, Ni, Mn, Mo, W, Pd, V, $\mathrm{Nb}, \mathrm{Ta}, \mathrm{Ag}$ ), ICP-atomic emission spectroscopy ( $\mathrm{Si}, \mathrm{Na}$, $\mathrm{K}, \mathrm{Li})$, Karl Fischer titration analysis $\left(\mathrm{H}_{2} \mathrm{O}\right)$, and neutralization titration analysis (HF).

\section{Results}

Figure 1 plots the measured weight change $\left(\Delta M_{\operatorname{Exp}}\right)$ of the hydrogen-permeation materials during exposure to Flinak at $873 \mathrm{~K}$ for $304 \mathrm{hr}$. The Pd-Ag, pure V, and Nb exhibited weight gain, while pure Ta lost weight. The weight change for a fusion blanket structural material (JLF-1 ferritic steel) is also plotted from previous data for comparison [4]. The weight loss of Ta is still not significant and is similar to JLF-1 steel, even for a longer corrosion time. Table 1 lists the chemical compositions of Flinak before and after the corrosion tests. $\mathrm{Pd}, \mathrm{Fe}, \mathrm{Cr}, \mathrm{Ni}, \mathrm{Mo}, \mathrm{Mn}, \mathrm{Si}$, and $\mathrm{H}_{2} \mathrm{O}$ were detected as impurities before the corrosion tests. The contamination source for the impurities, except for $\mathrm{Pd}$

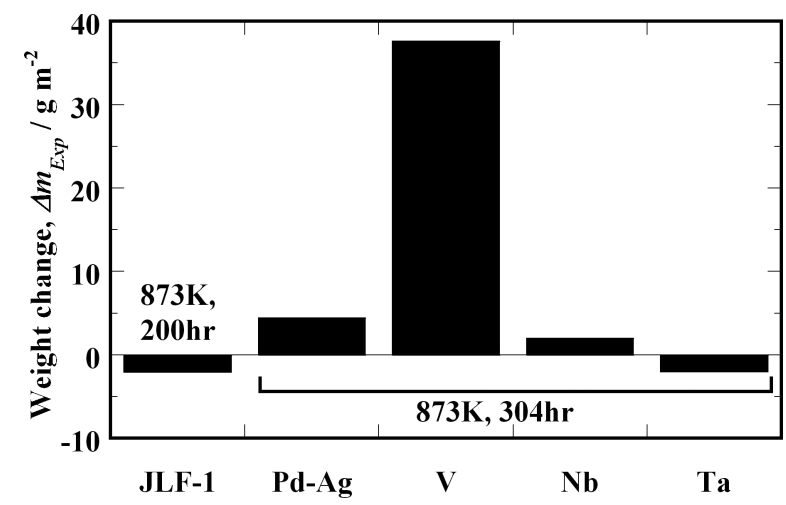

Fig. 1 Weight change of hydrogen-permeation materials during exposure to Flinak at $873 \mathrm{~K}$ for $304 \mathrm{hr}$. and $\mathrm{H}_{2} \mathrm{O}$, is assumed to be the stainless steel crucible used in refining the Flinak. $\mathrm{H}_{2} \mathrm{O}$ is thought to come from the refining atmosphere. Since no contamination source for Pd was involved in the refining process, $4.0 \mathrm{wppm}$ may be the detection limit for Pd. After the corrosion tests, the change in the concentration of Pd and $\mathrm{Ag}$ was negligible; however, the evident increase for $\mathrm{V}, \mathrm{Nb}$, and Ta indicated that the elements were dissolved into Flinak from specimens during the corrosion tests. HF concentration was below the detection limit in all conditions.

Figure 2 presents SEM images of the specimen surface before and after the corrosion tests. Particles smaller than $100 \mathrm{~nm}$ were observed. They coalesced and formed clusters in pure $\mathrm{V}, \mathrm{Nb}$, and Ta. Table 2 indicates the average size and areal number density of the particles and the clusters.

The composition of the corrosion products on the surface was analyzed by XPS with Ar sputtering. Figure 3 depicts the depth profiles for concentration of the elements. The sputtering rate was $4.9 \mathrm{~nm} / \mathrm{min}$ in $\mathrm{SiO}_{2}$ and did not significantly depend on the materials; thus, 30 min sputtering should be equivalent to about $150 \mathrm{~nm}$ depth from

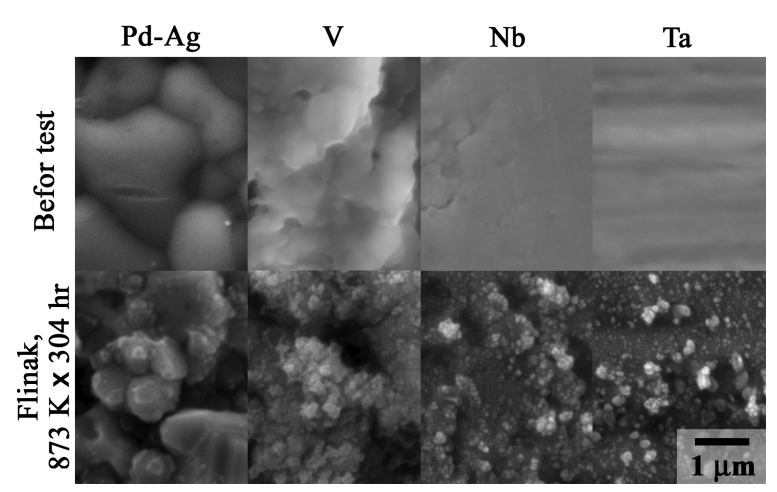

Fig. 2 SEM images of the specimen surface before and after the corrosion tests.

Table 1 Chemical compositions of Flinak before and after the corrosion tests (wppm, $\left.{ }^{*} w t \%\right)$.

\begin{tabular}{|c|c|c|c|c|c|c|c|c|c|}
\hline & & $\mathrm{Pd}$ & $\mathrm{Ag}$ & $\mathrm{V}$ & $\mathrm{Nb}$ & $\mathrm{Ta}$ & $\mathrm{Li}^{*}$ & $\mathrm{Na}^{*}$ & $\mathrm{~K}^{*}$ \\
\hline \multicolumn{2}{|c|}{ Before test } & 3.8 & $<0.01$ & $<0.01$ & $<0.01$ & $<0.01$ & & & \\
\hline \multirow{5}{*}{ After test } & Specimen & & & & & & & & \\
\hline & Pd-Ag & 4.0 & $<0.01$ & & & & 7.81 & 6.48 & 38.6 \\
\hline & V & & & 7.1 & & & 8.41 & 6.95 & 41.6 \\
\hline & $\mathrm{Nb}$ & & & & 34 & & 7.95 & 6.58 & 39.2 \\
\hline & $\mathrm{Ta}$ & & & & & 93 & 8.00 & 6.80 & 40.3 \\
\hline
\end{tabular}

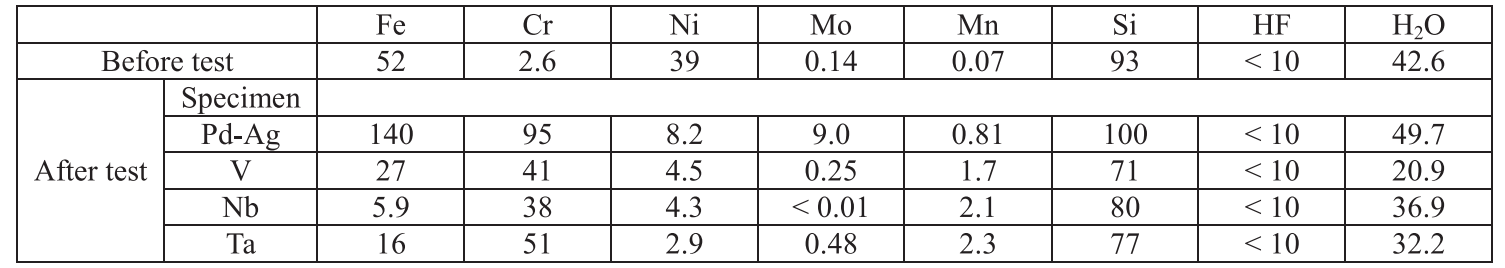


Table 2 Average size and areal number density of the corrosion products.

\begin{tabular}{|l|c|c|c|c|c|c|c|c|}
\hline & \multicolumn{2}{|c|}{ Pd-Ag } & \multicolumn{2}{c|}{ V } & \multicolumn{2}{c|}{ Nb } & \multicolumn{2}{c|}{ Ta } \\
\cline { 2 - 8 } & Particle & Cluster & Particle & Cluster & Particle & Cluster & Particle & Cluster \\
\hline Size/nm & 100 & & 40 & 270 & 60 & 250 & 30 & 210 \\
\hline $\begin{array}{l}\text { Areal number } \\
\text { density/\# m }\end{array}$ & $2.9 \times 10^{12}$ & & $1.4 \times 10^{14}$ & $2.4 \times 10^{12}$ & $1.3 \times 10^{14}$ & $8.2 \times 10^{11}$ & $1.1 \times 10^{14}$ & $3.8 \times 10^{12}$ \\
\hline
\end{tabular}
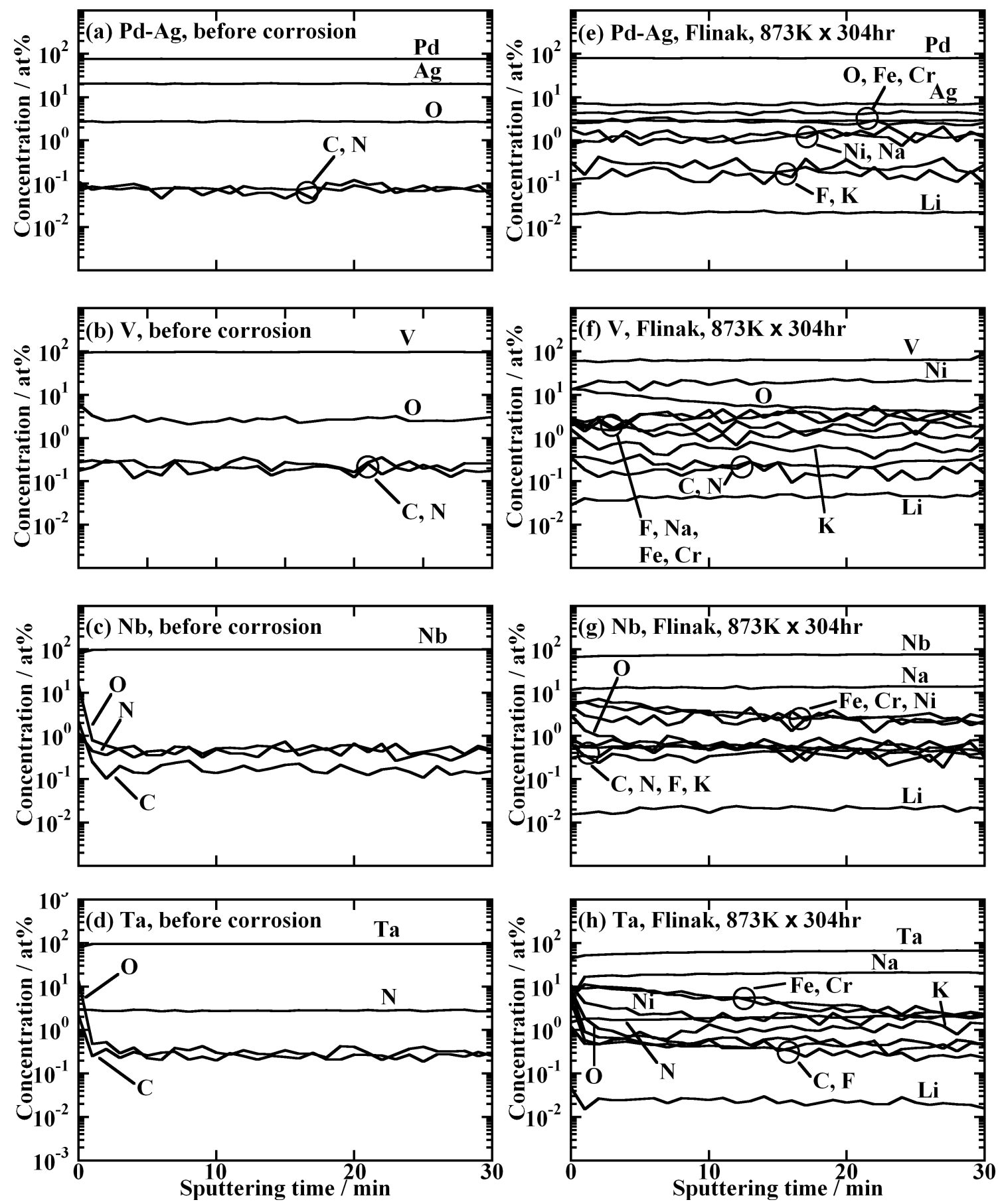

Fig. 3 Depth profile of the concentration of elements converted from photoelectron intensity. The sputtering rate was $4.9 \mathrm{~nm} / \mathrm{min}$ in $\mathrm{SiO}_{2}$. Photoelectrons analyzed were Li-1s, C-1s, N-1s, O-1s, F-1s, Na-1s, K-2p, V-2p, Cr-2p, Fe-2p, Ni-2p, Nb-3d, Pd-3d, Ag-3d and Ta-4f. 
the surface. The concentration of Ag decreased after the corrosion test for the Pd-Ag specimen. Figures 3 (a)-(d) indicate that the surface of the specimen was partially oxidized before the corrosion tests. Compared with the $\mathrm{O}$ concentration before corrosion, the increase in $\mathrm{O}$ concentration was more significant for the $\mathrm{V}$ specimen than for the other specimens. The Na concentration increased after the corrosion test for $\mathrm{Nb}$ and $\mathrm{Ta}$ specimens.

\section{Discussion}

\subsection{Weight change during the corrosion tests}

As plotted in Fig. 1, weight loss was detected in only pure Ta, whereas weight gain was detected in the other materials. Weight loss is understood to be due to dissolution of corrosion products into Flinak, while the corrosion products can gain weight if they remain on the surface. The contribution of the remaining corrosion products can be estimated with the following equation.

$$
\Delta M_{\mathrm{CP}}=\frac{4}{3} \pi\left(\frac{d_{\mathrm{P}}}{2}\right)^{3} \rho_{\mathrm{X}} N_{\mathrm{P}}+\frac{4}{3} \pi\left(\frac{d_{\mathrm{C}}}{2}\right)^{3} f \rho_{\mathrm{X}} N_{\mathrm{C}}
$$

$\Delta M_{\mathrm{CP}}$ : Weight change by corrosion products $\left(\mathrm{g} \mathrm{m}^{-2}\right)$ $\rho_{\mathrm{X}}$ : Mass density of corrosion product $\mathrm{X}\left(\mathrm{g} \mathrm{m}^{-3}\right)$ $d_{\mathrm{P}}$ : Diameter of corrosion product particles $(\mathrm{m})$ $N_{\mathrm{P}}$ : Number density of particles $\left(\mathrm{m}^{-2}\right)$ $d_{\mathrm{C}}$ : Diameter of corrosion product clusters $(\mathrm{m})$

$N_{\mathrm{C}}$ : Number density of clusters $\left(\mathrm{m}^{-2}\right)$ $f$ : Volume fill fraction of clusters.

Here, it is assumed that the corrosion product clusters are formed by coalescence of the corrosion product particles with the volume fill fraction $(f)$. The $\mathrm{O}$ concentration was 3 to 7 times higher than the F concentration (e.g., in Fig. 3 (f) for pure V, which exhibited a large weight gain); therefore, the corrosion products should be mainly oxide. Figure 4 presents Gibbs free energy of formation calculated by the MALT code $[5,6]$ for oxides related to the element detected in Fig. 3. Only data for solid-state oxides are presented in Fig. 4, except for $\mathrm{H}_{2} \mathrm{O}$ (gas state). Since $\mathrm{NaNbO}_{3}$ is stable, the high $\mathrm{Na}$ concentration in Fig. $3(\mathrm{~g})$ was probably caused by its formation. According to the high $\mathrm{Na}$ concentration in Fig. 3 (h), $\mathrm{NaTaO}_{3}$ is also possibly a stable oxide; however, its data are not currently available. Table 3 indicates the weight gain induced by the remaining corrosion products, assuming that they are the most stable oxides at $873 \mathrm{~K}$ in Fig. 4 and $f=0.5$ in Eq. (1). In this analysis, the average size in Table 2 is used for the diameter of the particles and the clusters, and the areal number density in Table 2 is used for their number density. The estimated weight gain is small compared with the measured weight gain observed in Fig. 1; therefore, the remaining corrosion products on the surface do not contribute significantly to weight gain.

An increase in the concentration of the constituent elements (e.g., $\mathrm{Pd}, \mathrm{Ag}, \mathrm{V}, \mathrm{Nb}$, and $\mathrm{Ta}$ ) in Flinak can result in

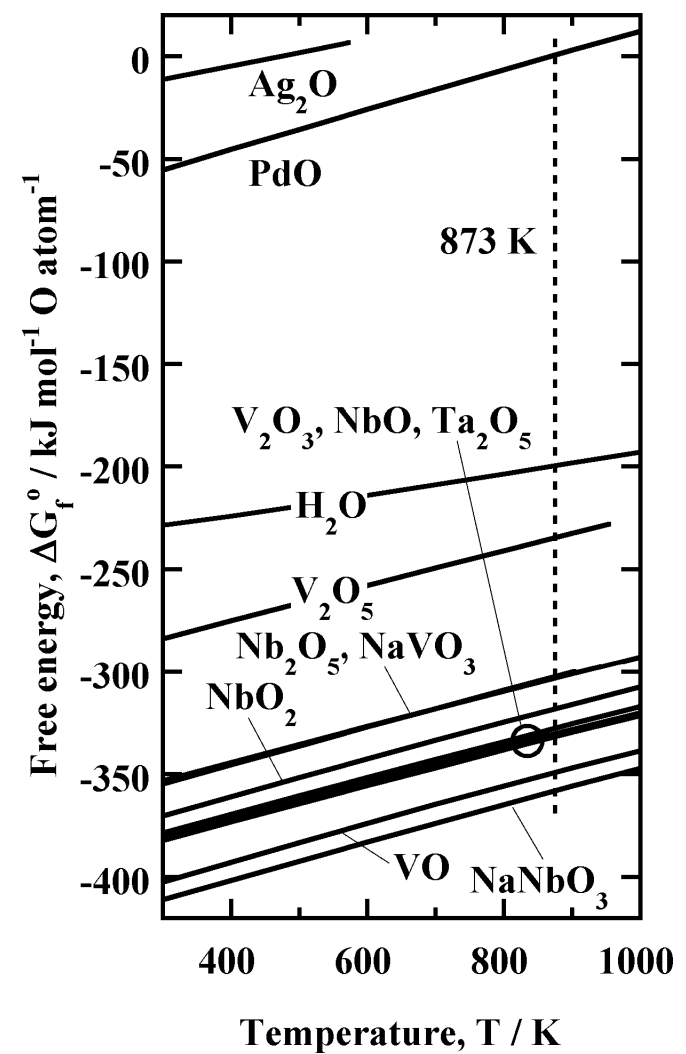

Fig. 4 Gibbs free energy of formation for oxides.

Table 3 Weight gain estimated with Eq. (1).

\begin{tabular}{|c|c|c|c|}
\hline & $\begin{array}{l}\text { Oxide, } \\
X\end{array}$ & $\begin{array}{l}\text { Density, } \rho_{X} \\
/ 10^{6} \mathrm{~g} \mathrm{~m}^{-3}\end{array}$ & $\begin{array}{c}\text { Weight change, } \\
\Delta M_{C P} / \mathrm{g} \mathrm{m}^{-2}\end{array}$ \\
\hline $\mathrm{Pd}-\mathrm{Ag}$ & $\mathrm{PdO}$ & 8.3 & +0.012 \\
\hline $\mathrm{V}$ & $\mathrm{VO}$ & 5.8 & +0.099 \\
\hline $\mathrm{Nb}$ & $\mathrm{NaNbO}_{3}$ & 4.6 & +0.083 \\
\hline $\mathrm{Ta}$ & $\mathrm{Ta}_{2} \mathrm{O}_{5}$ & 8.7 & +0.094 \\
\hline
\end{tabular}

weight loss for the specimens through the following equation:

$$
\Delta M_{\mathrm{D}}=-\frac{\Delta C M}{S} \times 10^{-6}
$$

$\Delta M_{\mathrm{D}}$ : Weight change caused by dissolution of the constituent elements $\left(\mathrm{g} \mathrm{m}^{-2}\right)$

$\Delta C$ : Concentration change of the constituent elements in Flinak (wppm)

$M$ : Weight of Flinak used $=10 \mathrm{~g}$

$S:$ Specimen surface area $=3.5 \times 10^{-4} \mathrm{~m}^{2}$.

Table 4 indicates the weight loss caused by the increase in the concentration indicated in Table 1. Since no difference in $\mathrm{Ag}$ concentration was detected, only the change in $\mathrm{Pd}$ concentration is taken into account for $\mathrm{Pd}-\mathrm{Ag}$ specimens. Since weight changes $\left(-0.0065\right.$ to $\left.-3.0 \mathrm{~g} \mathrm{~m}^{-2}\right)$ by dissolution are less than or similar to that for JLF-1 $\left(-2.08 \mathrm{~g} \mathrm{~m}^{-2}\right)$, their corrosion rate is expected to be insignificant com- 
Table 4 Weight loss estimated with Eq. (2).

\begin{tabular}{|c|c|c|}
\hline & $\begin{array}{c}\text { Concentration change, } \\
\Delta C / \mathrm{wppm}\end{array}$ & $\begin{array}{c}\text { Weight change, } \\
\Delta M_{D} / \mathrm{g} \mathrm{m}^{-2}\end{array}$ \\
\hline $\mathrm{Pd}-\mathrm{Ag}$ & +0.2 & -0.0065 \\
\hline $\mathrm{V}$ & +7.1 & -0.23 \\
\hline $\mathrm{Nb}$ & +34 & -1.1 \\
\hline $\mathrm{Ta}$ & +93 & -3.0 \\
\hline
\end{tabular}

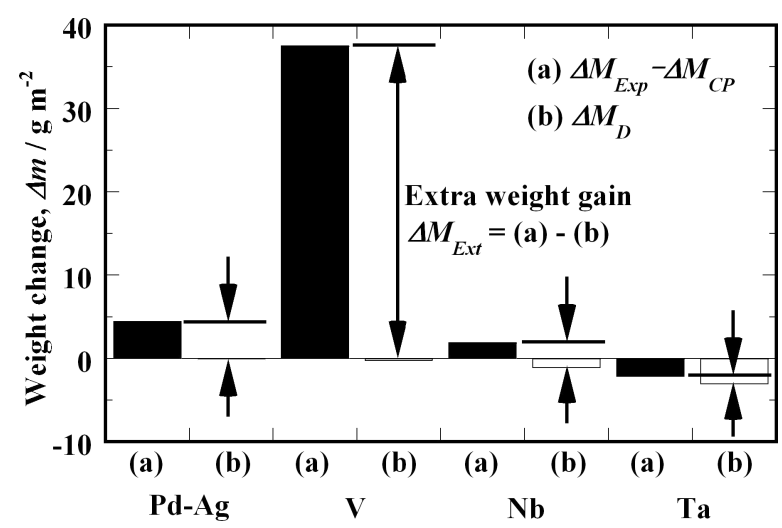

Fig. 5 Comparison between the weight changes obtained by different estimation.

pared with that of JLF-1.

Assuming that all the dissolved elements remained in Flinak after the corrosion tests, the weight change due to dissolution $\left(\Delta M_{\mathrm{D}}\right)$ (Table 4$)$ should be equal to the measured weight change calibrated with that by the remaining corrosion products $\left(\Delta M_{\operatorname{Exp}}-\Delta M_{\mathrm{CP}}\right)$ (Fig. 1 and Table 3$)$. Figure 5 plots the comparison of $\Delta M_{\mathrm{D}}$ and $\Delta M_{\mathrm{Exp}}-\Delta M_{\mathrm{CP}}$. The extra weight gain is defined as follows

$$
\Delta M_{\mathrm{Ext}}=\Delta M_{\mathrm{Exp}}-\Delta M_{\mathrm{CP}}-\Delta M_{\mathrm{D}} \text {. }
$$

The extra weight gain for pure $\mathrm{V}$ is positive and much greater than for the other specimens, and would be caused by weight change without the formation of corrosion products. According to the high solubility of $\mathrm{O}$ in pure $\mathrm{V}$ $(2.2 \mathrm{wt} \%$ at $873 \mathrm{~K})$, the $\mathrm{O}$ absorption into a solid solution state in pure $\mathrm{V}$ is a possible mechanism for the extra weight gain. The $\mathrm{H}_{2} \mathrm{O}$ impurity in Flinak is a probable source of $\mathrm{O}$ contamination. This is supported by the reduction in $\mathrm{H}_{2} \mathrm{O}$ concentration in the corrosion test with the $\mathrm{V}$ specimen (Table 1). However, the decrease in $\mathrm{H}_{2} \mathrm{O}$ concentration before exposure in Flinak (42.6 wppm) and after exposure in Flinak (20.9 wppm) can explain only $0.75 \mathrm{~g} \mathrm{~m}^{-2}$ weight gain. Considering that the extra weight gain $\left(\Delta M_{\mathrm{Ext}}\right)$ was $38 \mathrm{~g} \mathrm{~m}^{-2}$ for pure $\mathrm{V}$, other $\mathrm{O}$ sources must have been introduced. Possible sources are $\mathrm{O}_{2}$ in Flinak and $\mathrm{H}_{2} \mathrm{O}$ and $\mathrm{O}_{2}$ in the atmosphere for the exposure tests. Techniques for measurement and control of $\mathrm{O}_{2}$ in Flinak and also of $\mathrm{H}_{2} \mathrm{O}$ and $\mathrm{O}_{2}$ in the atmosphere are required for investigating the mass balance in the corrosion system. Figure 6 depicts $2 p$ photoelectron spectra and their peak separation

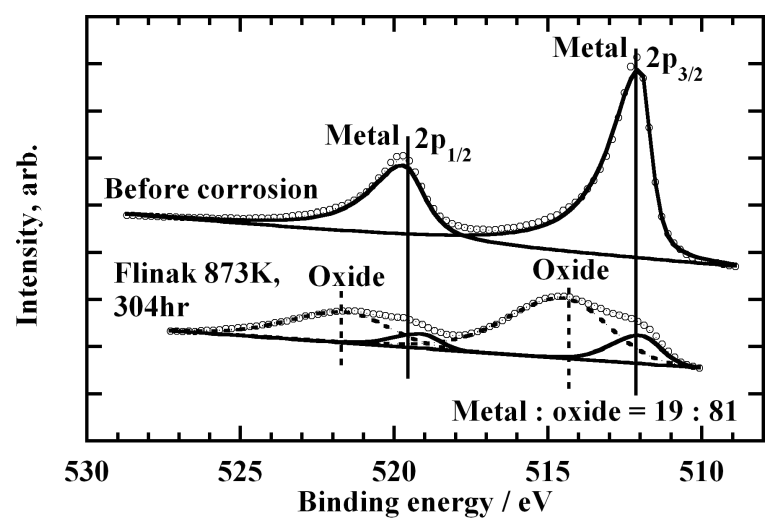

Fig. 6 V-2p photoelectron spectra on the surface of pure $\mathrm{V}$ before and after the Flinak corrosion test.

analysis for pure $\mathrm{V}$ before and after the corrosion test. The spectrum after the corrosion test can be separated into four peaks. The two peaks denoted by the dashed lines indicate a chemical shift due to oxide formation (e.g., VO, $\mathrm{V}_{2} \mathrm{O}_{3}$ and $\mathrm{V}_{2} \mathrm{O}_{5}$ ). The ratio of the $2 \mathrm{p}_{1 / 2}$ metal peak area to the oxide one is 19:81. The residual metal state area of the surface is assumed to absorb oxygen into a solid solution state. The diffusion range for oxygen in pure $\mathrm{V}$ is described with the following equations.

$$
\begin{aligned}
& R=\sqrt{D t} \\
& D=D_{0} \mathrm{e}^{-\frac{Q}{R T}}
\end{aligned}
$$

$R$ : diffusion range $(\mathrm{m})$

$D$ : Diffusion coefficient $\left(\mathrm{m}^{2} \mathrm{~s}^{-1}\right)$

$D_{0}$ : Constant $=2.46 \times 10^{-6} \mathrm{~m}^{2} \mathrm{~s}^{-1}$ [7]

$Q:$ Activation energy $=1.23 \times 10^{5} \mathrm{~J} \mathrm{~mol}^{-1}[7]$

$R:$ Gas constant $=8.3144 \mathrm{~J} \mathrm{~mol}^{-1} \mathrm{~K}^{-1}$

$T:$ Temperature $=873 \mathrm{~K}$.

The diffusion range of $\mathrm{O}$ in $\mathrm{V}$ at $873 \mathrm{~K}$ for $304 \mathrm{hr}$ is obtained as $330 \mu \mathrm{m}$. Assuming that pure V after the Flinak corrosion contains as much $\mathrm{O}$ as the solubility limit (2.2 $\mathrm{wt} \%$ ), weight gain produced from the solid solution of $\mathrm{O}$ is derived from the following equation.

$$
\Delta M_{\mathrm{S}}=R \rho_{\mathrm{V}} C \times 10^{-2}
$$

$\Delta M_{\mathrm{S}}$ : Weight gain induced by solid solution $\mathrm{O}$ in pure $\mathrm{V}$ $\left(\mathrm{g} \mathrm{m}^{-2}\right)$

$\rho_{\mathrm{V}}$ : Mass density of $\mathrm{V}=6.11 \times 10^{6} \mathrm{~g} \mathrm{~m}^{-3}$

$C$ : Solubility limit of $\mathrm{O}$ in pure $\mathrm{V}=2.2 \mathrm{wt} \%$.

The weight gain induced by solid solution $\mathrm{O}$ in pure $\mathrm{V}$ $\left(\Delta M_{\mathrm{S}}\right)$ is calculated as $44 \mathrm{~g} \mathrm{~m}^{-2}$, which is roughly consistent with $\Delta M_{\mathrm{Ext}}$ for $\mathrm{V}\left(38 \mathrm{~g} \mathrm{~m}^{-2}\right)$. The extra weight gain, therefore, can be understood by $\mathrm{O}$ absorption into pure $\mathrm{V}$ during the corrosion test. Since no reliable data for the solubility limit and the diffusion coefficient of $\mathrm{O}$ are available for the other materials (e.g., Pd-Ag, pure $\mathrm{Nb}$, and Ta), analysis of $\Delta M_{\mathrm{S}}$ was impossible and should be studied further. 
In addition, it is a concern that $\mathrm{O}$ absorption might induce hardening and embrittlement, especially for $\mathrm{V}$ and $\mathrm{Nb}$ [8]. Analysis of mechanical properties is necessary to confirm if these materials maintain enough ductility even after the $\mathrm{O}$ absorption in Flinak.

\subsection{Dissolution of highly radioactive element}

The average concentration of $\mathrm{Ag}$ from 0 to $30 \mathrm{~min}$ (Fig. 3) decreased from 21 to $7.7 \mathrm{wt} \%$ (21 to 7.0 at $\%$ ). This result indicates that some $\mathrm{Ag}$ was dissolved into Flinak. Since the melting point of $\mathrm{Ag}$ oxide $\left(\mathrm{Ag}_{2} \mathrm{O}\right)$ is $573 \mathrm{~K}$, this compound would easily dissolve in Flinak at $873 \mathrm{~K}$. However, the change in Ag concentration in Flinak was below the detection limit (Table 1). The dissolution of Ag might be too small to detect. Systematic corrosion tests with longer time conditions are required to clarify the dissolution rate of $\mathrm{Ag}$ into Flinak.

In addition, the dissolution of $\mathrm{Nb}$ during the corrosion tests was evident from Table 1 . Ag and $\mathrm{Nb}$ are highly radioactive elements that are restricted below the level of 0.01 to $0.1 \mathrm{wppm}$ in the blanket structural materials $[9,10]$. Ta was also dissolved; however, this is not as important from the viewpoint of radioactivity. $\mathrm{Ag}$ and $\mathrm{Nb}$ elements are transferred by the breeding materials to the fusion reactor core, and possibly induce remarkable radioactivity, which may conflict the handling of the breeding materials in operation and after the reactor shutdown. Neutronics analysis of breeding materials is required to determine the acceptable dissolution limits for $\mathrm{Ag}$ and $\mathrm{Nb}$ in molten salt. The dissolution characteristics of the radioactive elements in Flinak may differ from those in Flibe. Further investigation of dissolution characteristics is necessary for Flinak for the Orosh ${ }^{2} \mathrm{i}-1$ project and for Flibe blanket system for fusion reactors.

\section{Conclusions}

The Orosh ${ }^{2}$ i-1 project has been initiated to integrate numerous elemental studies of the molten salt blanket. The present study investigated the corrosion characteristics of candidate hydrogen-permeation materials (e.g, Pd-Ag, V, $\mathrm{Nb}$, and $\mathrm{Ta}$ ) for the hydrogen-recovery section of Orosh ${ }^{2} \mathrm{i}-$ 1. It was determined that the corrosion rate expected from the weight change by dissolution was insignificant in Flinak at $873 \mathrm{~K}$ under static conditions compared with that of the fusion blanket structural material (JLF-1 ferritic steel). However, pure $\mathrm{V}$ exhibited a relatively high weight gain, likely due to $\mathrm{O}$ absorption, which might induce degradation of mechanical properties. Dissolution of $\mathrm{Ag}$ and $\mathrm{Nb}$ was indicated and would induce high radioactivity for breeding materials. Examination of the mechanical properties of the hydrogen-permeation materials and neutronics analysis of the dissolved elements are necessary to develop a hydrogen-recovery section for the Orosh ${ }^{2} \mathrm{i}-1$ Flinak loop system and a Flibe blanket system for fusion reactors.

\section{Acknowledgements}

This work was supported by JSPS KAKENHI Grantin-Aid for Scientific Research (A) 21246141 and NIFS budget code NIFS08UCFF002. The authors are grateful to Ms. Ohshima for the Flinak corrosion tests.

[1] A. Sagara et al., Fusion Eng. Des. 81, 2703 (2006).

[2] S. Fukada et al., Fusion Sci. Technol. 41, 1054 (2002).

[3] S. Fukada et al., Fusion Eng. Des. 81, 477 (2006).

[4] M. Kondo et al., The 9th Intl. Sympo. Fusion Nucl. Technol. (ISFNT-9), Oct. 11-16, 2009, Dalian China.

[5] S. Yamauchi, Netsu Sokutei 12, 142 (1985) (in Japanese).

[6] H. Yokokawa, Netsu Sokutei 12, 144 (1985) (in Japanese).

[7] R.C. Svedberg and R.W. Buckman, Jr., Intel. Met. Rev. 25, 223 (1980).

[8] D.L. Harrod et al., Intl. Met. Rev. 25, 163 (1980).

[9] E.T. Cheng et al., J. Nucl. Mater. 258-263, 1767 (1998).

[10] Y. Wu et al., J. Nucl. Mater. 307-311, 1026 (2002). 